\title{
Identification of Emotional Intelligences Level through Brainstorming Method and Its Impact on Students' Academic Achievement
}

\author{
Almubarak \\ Chemistry Education Department, Faculty of Teacher Training and Education \\ Universitas Lambung Mangkurat \\ Banjarmasin, Indonesia \\ almubarak_kimia@unlam.ac.id
}

\begin{abstract}
This study aimed to identify the level of emotional intelligences through brainstorming method and its impact on students' academic achievement. This study used quantitative descriptive research. The samples were determined by using purposive sampling technique from the students of Chemistry Education, Faculty of Teacher Training and Education, Lambung Mangkurat University. Data collection techniques used emotional intelligences instrument, cognitive test, and student motivation questionnaire. Data analysis techniques used multiple linear regression and partial regression coefficient test (t test, sig 0.05). The finding showed that the average levels of students' emotional intelligences were EA 23.46 EM 27.16, SEA 28.02, RM 27.32 and academic achievement (AA) 74.43. Then, EA 0.392, EM 0.015, SEA 0.264, RM 0.478. It can be concluded that emotional intelligence has given an impact on students' academic achievement.
\end{abstract}

Keywords-Academic Achievement, Brainstorming, Emotional Intelligences

\section{INTRODUCTION}

Emotional intelligence is how individuals understand their own feelings, empathize with the feelings of people around them and regulate emotions in different ways. Emotional intelligence may be more important and needed to get a success than IQ (Intelligence Quotient). If IQ is not achieved then emotional intelligence will accommodate it. The statement concluded that every individual has the potential of generating an idea through their emotional intelligence and to develop their potential in various fields. Salovey emotional intelligence has been classified into five regions [1].

Emotional intelligence distributes much of the students' academic achievement. This is due to student's ability to control emotions while learning, by not suppressing their feelings. However, to make the given problem as a process find a solution, the solution process is an activity that is considered positive in order to create stable conditions and without pressure. Motivation in emotional intelligence is seen as the basis to improve the success rate in various fields, particularly the achievement. Achievement is supported through a set of feelings such as enthusiasm, passion in learning, and selfconfidence. Some people are able to achieve at a high level, it is because the individual has a level of toughness and great diligence and was based on the nature of enthusiasm, conviction, and courage to face the challenges [1].

Emotional intelligence was first used as a term of a dissertation of Wayn Payne (1985), followed by Salovey and Meyer (1990) and Goleman (1995). The term was later developed into an essential examined and discussed in the 2000s. Emotional intelligence relates to what person should do and not do in the learning environment [2][3][4][5]. This is closely related to how the students take a decision with positive thinking, brave, motivated, and completely true [3][5]. Decision making is a specific cognitive concepts in moral terms [2].

Linda Bryant argues that "emotional intelligence in the education field is considered very important [6][7][8] as a concept/approach that can contribute to the process of teaching and learning", other concepts such as Gadner in multiple intelligences [9], Mihalyi Csikzent-Mihalyi's flow concept [6]. Related to this, educators should be a major actor in the classroom, where teachers have the ability to combine learning theories through multi-learning. The implementation of learning theory and multi-learning will lead students to understand their personal learning, so that the learning process will be easy. Then, students can understand that emotional well distributed while learning in the classroom is intelligence [10][5]. Indirectly, the scenario has been planned by the educator will have an impact on the emotional intelligence level of students and make it easier to analyze the level of knowledge, attitude, personality, and cognitive during the process of teaching in the classroom [6][11].

Research results by Walter Mischel from Stanford Psychology University [6] showed that individuals with high emotional intelligence through measurement [12][13] is a person who has the potential to succeed in the future because he understands his ability to make decisions and solve problems [5] emotionally. It deals with the provision of treatment to students who will be analyzed through an assessment of emotional intelligence. These results have the basic assessment consists of several measurement indicators 
such as self-awareness, self-regulation, motivation, empathy, and social skill [14].

Treatment in learning is the most important thing that must be considered by the teacher. Application of models, methods, strategies, and even learning atmosphere affect cognition, attitudes, motivations and moral development of students [15]. Through the application, teachers will be easier to form the character and moral as well as an analysis of learning styles and emotional intelligence of students [16]. Individual moral development is closely related to their development emotionally and then brings students into the real meaning of emotional intelligence [5][15]. In the process of learning, emotional intelligence is rated as abilities [17] to identify, assess and control emotions like attitude [18], cognitive, motivational [5][10][17]. Good teaching is a study condition that could lead to creative ideas and the stability of their learning process [18]. That process will not only generate a smart idea but could shape the behavior of the students were polite, controlled and oriented on their emotional intelligence [18].

Learning by brainstorming is a good treatment to achieve an effective learning process but not only have an impact on students' cognitive [19]. The learning process with a systematic brainstorming technique will improve student learning outcomes significantly and implementation is high cognitive performance [20]. In this connection, other factors (attitude, morale, creativity, and motivation) in addition to academic achievement (cognitive) took effect on the emotional state of students, so it was concluded that the integration of brainstorming in the study will accommodate the emotional intelligence of students [21][22][20]. Brainstorming oriented emotional intelligence will also have an impact on communication and enhance the activity of students in learning, then learning will be centered to students [23]. Through the formation of small groups in the classroom and SCL approach, then brainstorming will motivate students during the learning process takes place. Processes that occur during learning is a process where students entrust themselves to active and can contribute something [23].

Ref. [23] says that learning through brainstorming will improve and increase the linguistic students in learning. [24] The use of brainstorming strategies in learning will develop students' creativity in solving problems and establish communication skills, so that not only the creativity of students growing, but also the knowledge and way of thinking. Brain brainstorming will make students think creatively, critical and develop their knowledge in resolving problems [25]. In line with [17] that emotional intelligence is when people can understand, listen, feel, and express what they want with the procedure and the correct concept. The linkage is definitely related to the achievement of emotional intelligence (selfawareness skills, self-control, self-motivation, empathy, and social-skills) [17].

\section{METHOD}

This research method of this study was descriptive quantitative [26]. The purpose of this study is to identify the level of student emotional intelligence and academic achievement through brainstorming learning method. In addition, students' motivation in the learning process is also a measure in this study.

Research conducted at Chemistry Education Program of Lambung Mangkurat University. Research sample was the students of Chemistry Education of academic with the number of 42 students who were determined by purposive sampling technique. The sampling technique was based on several considerations related to samples, variables and courses selected. The data were analyzed by using multiple linear regression analysis and partial regression coefficient test using SPSS 22.0 program [27].

\section{FINDINGS}

Chart below is an illustration of the value of the average level of emotional intelligence and students achievement successively Emotional Awareness (EA) 23:46 Emotional Management (EM) 27.16, Social Emotional Awareness (SEA) 28.02, Relationship Management (RM) 27.32 and Academic Achievement (AA) 74.43. Based on the data that have been mentioned, it can be seen that the Social Emotional Awareness is the most dominant emotional intelligence or emotional intelligence which is high among other analyzed criteria. The AA point showed that students' academic achievement is in a good category.

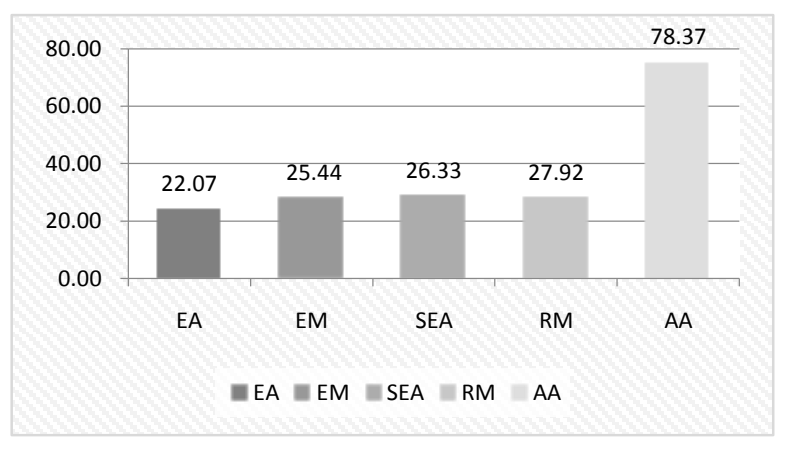

Fig. 1 The average of emotional intelligences level

Based on the results of the data analysis, the concept of emotional intelligence gives impact on student achievement. The same thing is also shown on the statistical data that is processed. Descriptive data showed statistical description of the beginning of the data as the mean of each dimension Learning Outcomes (academic achievement), Emotional Awareness (EA), Emotional Management (EM), Social Emotional Awareness (SEA), and Relationship Management (RM): 78.37, 22.07, 25.44, 26.33, and 27.93. Then, the data regression showed that there is a relationship of emotional intelligence on learning achievement. The score of the academic achievement is considered good with the category of emotional intelligence that is in either category. Therefore, it shows that through these methods, it can affect the emotional intelligence and academic achievement so that both have a relationship. 
TABLE I. VARIABLES ENTERED/REMOVED ${ }^{\mathrm{A}}$

\begin{tabular}{|l|c|c|c|}
\hline Model & Variables Entered & Variables Removed & Method \\
\hline 1 & RM, EA, EM, SEA ${ }^{\text {b }}$ & Enter \\
\hline \multicolumn{4}{|c}{ a. } \\
Dependent Variable: AA \\
b. All requested variables entered
\end{tabular}

TABLE II. ANOVA $^{\mathrm{A}}$

\begin{tabular}{|c|l|c|c|c|c|c|}
\hline \multicolumn{2}{|c|}{ Model } & $\begin{array}{c}\text { Sum of } \\
\text { Squares }\end{array}$ & df & $\begin{array}{c}\text { Mean } \\
\text { Square }\end{array}$ & F & Sig. \\
\hline \multirow{3}{*}{1} & Regression & 14.34 & 4 & 3.59 & .18 & $.95^{\mathrm{b}}$ \\
\cline { 2 - 7 } & Residual & 749.33 & 38 & 19.72 & & \\
\cline { 2 - 7 } & Total & 763,67 & 42 & \multicolumn{2}{|c|}{ a. Dependent Variable: AA } \\
\hline \multicolumn{7}{|c|}{}
\end{tabular}

TABLE III. COEFFICIENTS ${ }^{\mathrm{A}}$

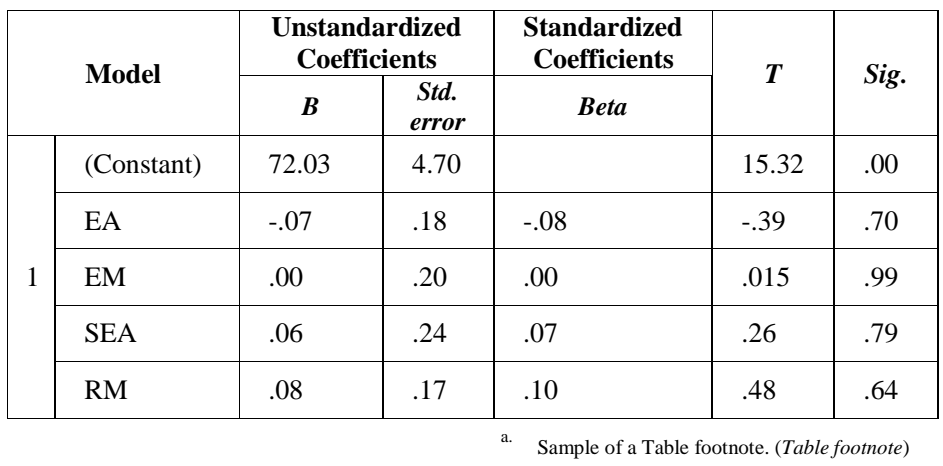

Coefficient data table above indicating that there is a relationship or emotional intelligence influencing students chemistry achievement. With regard to the statistics shown by the table, the value of the constant 72.03 with the t test results for 15.32 , df 4 and significance 0.000 . Thus, the hypothesis Ho was rejected; no connection or influence on students' emotional intelligence chemistry and $\mathrm{H} 1$ was accepted: no relationship or emotional intelligence influencing on students chemistry achievement. This conclusion is derived from the results of the $\mathrm{t}$ test through multiple linear regression analysis that Ho is rejected if th $<\mathrm{t}$ table, significance $<0.005$. EA 0.39, EM 0.02, SEA 0.26, RM 0.48 showed that $\mathrm{t}$ ht $<\mathrm{t}$ tb (2.024) which meant that emotional intelligence has given an impact on students' academic achievement and Sig. $0.00<0.005$. This value is clearly concluded that Ho was rejected and $\mathrm{H} 1$ was accepted that there is a relationship or emotional intelligence influence on student achievement chemistry. This hypothesis is strengthened beyond theory, also based on the results of statistical data analysis carried out which clarifies the relationship or significant influence.

Multifactorial phenomenon of a student's academic success has been studied extensively over the past few decades, although many studies focused only on cognitive factors. In a fatherly attempt to explore the importance of other factors in student achievement, study related to emotional intelligence (EI) and academic achievement appears [28, 29, 30, 31, 32]. The above data are similar to that described studies that the role of emotional intelligence is very influential on the achievement of students' academic achievement.

The literature review has also shown that emotional intelligence is very supportive of student's social and cognitive development [33], which is an advantage in some contexts, especially in educational settings. In fact, emotional knowledge related to the adjustment of students in academic and achievement, positive social behavior, achievement test, and evaluation [34]. In addition, students with emotional competence the higher setting goals greater academic and reflect a better level of self-discipline, motivation, regulation of stress, work organization, curiosity and has a higher value [35][36].

In addition, the emotional ability can be a key in social interaction: the expression of emotion positive students where they are likely to receive feedback and comments from others, whereas the expression of emotional disposition will have the opposite effect [37]. Thus, the power level of emotional intelligence has to predict students' academic value through the ability to interact, collaborate across study groups, and assessment [38]. Based on the statement are discussed, that the method of brainstorming undertaken is able to accommodate students' identification of emotional intelligence and emotional intelligence influence on student achievement. Thus, emotional intelligence has relevance to student achievement, and certainly with regard learning design chosen as the basis for identifying these things.

\section{CONCLUSION}

Based on the research that has been done, the emotional intelligence has a relationship or influence on student academic achievement to which can be seen through the data analysis done and presented on this study. Then, brainstorming method used is also described according to the theory that this method is able to accommodate the learning so that students are able to develop creativity and potential either cognitive or emotional intelligence to become future generations that have potential, science, talent and value.

\section{REFERENCES}

[1] Goleman, "Emotional Intelligence", New York: Bantam Book, 1995.

[2] R. Hinde and J. Stevenson, "Interpersonal relationship and child development", Development Review, vol. 7, pp. 1-21, 1987.

[3] Kohlberg, "Moral stage and moralization. the cognitive development approach in moral development and behavior theory", Research and Social Issue, pp. 33-47, 1976.

[4] Kulaksizoglu, "Secondary school students' moral judgment competence: a comparison between Samsun-turkey and Lancashire-england", mamara universitesi A.E.F Egitim Bilimleri Dergisi, vol. 7, pp. 185-188, 1995.

[5] Aybek, E. C. Can, Cavdar, Duygu, Nilufe, and T. Mutlu, "University studnets' moral judgment and emotional intelligence level : A model testing", Social and Behavior Science, vol. 191, pp. 2740-2746, 2015.

[6] N. J. Salkind, "Encylopedia of Educational Psychology", K. Rasmussen, Ed, Los Angeles, London, New Delhi, \& Singapore: SAGE, 2008.

[7] Goleman, "Working with Emostional Intelligence", New York: Bantam, 1998. 
[8] Emma, "Emotional competence and drop-out rates in higher education", Education + training, pp. Vol 50 Iss 2 pp. 18-139, 2008.

[9] T. Anderson, "Multiple Intelligences: in the Classroom", Alexandria, Virginia USA: ASCD, 2009.

[10] Salovey, Mayer and Caruso, "The Positive Psychology of Emotional Intelligence", C R Synder and S I Lopes (Handbook of Positive Psychology ed, Oxford: Oxford University Press, 2002.

[11] R. Cain and G. Cain, "Making Conncetion: Teaching and The Human Brain", Alexandria: Association for Supervision and Curriculum development, 1991.

[12] B. K, Bar-On and T, "Emotional expression and implication for occupational stress; an application of the emotional quotient inventory (EQ-i)", Personality and Individual Differences, vol. 28, pp. 11071118, 2000.

[13] J. M. Batista, F. W. Saris and R, "Effect of respone scale on assessment of emotional intelligence competencies", Personality and Individual Difference, vol. 46, pp. 575-580, 2009.

[14] R. Bar-On, "The bar-on model of emotional social intelligence (ESI)", Psicothema, vol. 18, pp. 13-25, 2006.

[15] M. Piechowski, "Development Potential”, Dubque: Kendal/Hunt, 1979.

[16] J. Changeux, "Etigin Dogal Temelleri”, Istanbul: Dotuk Yay, 2002.

[17] Goleman, "Emotional Intelligence: why it can matter more than IQ, $10^{\text {th }}$ anniversary ed", New York: Bantam Books, 2006.

[18] C. R. Emami, M. H. Yarmohamadiya and A. Golami, "The effect group plays on the development of the creativity of six-year children", Social and Behavior Science, vol. 15, pp. 2137-2141, 2011.

[19] R. T. Herschel, "The impact of varying gender composition on group brainstorming peformance in a GSS environment," Computer in Human Behavior, vol. 10, no. 2, pp. 209-222, 1994.

[20] Paul, and R. Rao, "Emotional intelligence: The sine qua non for a clinical leadership toolbox", Journal of Communication Disorders, vol. 39, no. 4, pp. 310-319, 2006.

[21] N. Eisenberg, A. Fabes R, K. Guthrie I, and M. Reiser, "Dispositional emotionality and regulation: their role in predicting quality of social functioning", Personal Social Psychology, vol. 78, pp. 136-57, 2000.

[22] D. P. Salovey, and J. Mayer, "Emotional intelligence. Imagination", Cognition \& Personality, vol. 9, pp. 185-2111, 1990.

[23] Bearing, N. Unin and P, "Brainstorming as a way to approach studentcentered learning in the ESL Classroom", Social and Behavioral Science, vol. 224, pp. 605-612, 2016.

[24] AlMutairi and A. N. Mohammad, "The effect of using brainstorming strategy in developing creative problem solving skills among male students in kuwait: a field study on saud al-kharji school in kuwait city", Journal of Education and Practice, vol. 6, no. 3, 2015.

[25] K. Far, M. Reza, N. Eshafani and A, "The effect of active approach in the experience science on the students' successful", Journal of Knowledge Reasearch Magazine, Teharn, 2001.

[26] Sugiyono, "Metode Penelitian Pendidikan (Pendekatan Kuantitatif,
Kualitatif, dan R\&D)”, Bandung, Indonesia: Alfabeta, 2016.

[27] D. Priyanto, "Olah Data Statistik dengan Program PSPP Alternatif SPSS”, Yogyakarta: PT. Buku Seru, 2013.

[28] K. A. Barchard, "Does emotional intelligence assist in the prediction of academic success ?", Educational and Psychological Measurement, vol. 63, pp. 840-858, 2003.

[29] M. Jr. R. O'Connor and S. Little I, "Revisiting the predictive validity of emotional intelligence: Self-report versus ability-based measures", Personality and Individual, vol. 35, pp. 1893-1902, 2003.

[30] A. Parker JD, S. Creque, L. Benhart D, I. Harris J, A. Majeski. S and L. Wood, "Academic achievement in high school: Does emotional intelligence matter ?", Personality and Individual Differences, vol. 37, p. 1321-1330., 2004.

[31] V. Petrides K, N. Frederickson and A. Furnham, "The role of trait emotional intelligence in academic performance and deviant behavior at school", Personality and Individual Differences, vol. 36, pp. 277-293, 2004.

[32] S. Schute N, M. Malouff J, E. Hall L, J. Haggerty D, T. Cooper J, and J. Golden C, "Development and validation of a measure of emotional intelligence", Personality and Individual Differences, vol. 25, p. 167177, 1998.

[33] G. Helberstadt A, A. Denham S and Dunsmore, "Affective social competence", Development, vol. 10, pp. 79-119, 2001.

[34] T. Greenberg M, P. Weissberg R, U. O'Brien M, E. Zins J, L. Fredericks \& H. Resnik, "Enhancing school-based prevention and youth development through coordinated social and emotional learning", American Psychologist, vol. 58, p. 466-474, 2003.

[35] L. Duckworth A and EP. Seligman M, "Self-discipline outdoes IQ in predicting academic performance of adolescents", Psychological Science, vol. 16, no. 12, p. 939-944, 2005.

[36] J. Elliot A and S. Dweck C, "Competence and motivation: Competence as the core of achievement motivation, in A. J. Elliot, \& C. S. Dweck Edition ed", New York: Handbook of competence, 2005.

[37] M. Argyle and L. Lu, "Happiness and social skills", Personality and Individual Differences, vol. 11, pp. 1255-1261, 1990.

[38] C. McCan, G. Forgarty, M. Zeindner and R. Robert, "Coping mediates the relationship between emotional intelligence (EI) and academic achievement", Contemporary Educational Psychology, vol. 36, no. 1, pp. 60-70, 2011. 